\title{
Comparative evaluation of alcoholic handrub: science or marketing?
}

\author{
Philippe Berthelot ${ }^{1^{*}}$ and Martin Exner $^{2}$
}

We read with interest but also with some astonishment the paper of Kampf et al. [1] comparing the efficacy of three alcoholic-based hand-rubs (ABHR) according to EN 1500 and EN 14476. This study highlighted the possible variability of the results in different laboratories suggesting that the norm methods must be improved for a better standardization (EN 1500 and PrEN 1500). Although the methodology of the experiments seems robust, we do not understand why only three products used in French hospitals were tested and why the positive list of the French Society for Hospital Hygiene (SFHH) was targeted by Kampf et al. in the tittle and in the discussion section of the paper. As two of the authors are employed by Bode Chemie GmbH, a competing company of the French companies that manufactured the ABHR tested, there are real competing interests as mentioned at the end of the paper. We want to underscore also that this kind of paper is able to discredit some widely used products, represents a threat to hand hygiene promotion and the confidence in disinfectants if it is misunderstood and misused.

As for some other controversial papers about the efficacy of ABHR [2-4] the French Society for hospital Hygiene and the Disinfectant Commission of the German Association for Applied Hygiene (VAH) ${ }^{\mathrm{a}}$ want to remind that independent testing of disinfectants is an important criterion to select active from non- active substances and therefore an essential instrument for quality assurance for disinfectants. To guarantee the activity and reliability under practical conditions the education of healthcare workers in the application of efficient hand disinfectants is a key point. The role of hospital hygiene societies is to promote efficient hand rub use for better hand hygiene in healthcare settings. In 2010, the SFHH choose to end the positive list and begin the writing of guidelines to help healthcare settings to choose disinfectants. The SFHH (now named SF2H) never claimed to be able to control

\footnotetext{
* Correspondence: philippe.berthelot@chu-st-etienne.fr

'French Society for Hospital Hygiene (SF2H), Saint-Etienne, France

Full list of author information is available at the end of the article
}

completely the validity of the tests performed and always reminded the readers that the manufacturers and the laboratories that tested the products were responsible for the results of the efficacy tests. On the contrary of Germany, the French Society for Hospital Hygiene do not evaluated on its own responsibility the efficacy of the products. The analyses of the test reports provided by the manufacturer were free and independent. We think that the French positive list has had a positive impact to promote handrub use and despite its limitations permitted to select adequate products for use in healthcare settings [5]. These efforts are necessary also for the future. In Germany the list of tested and by an independent commission of experts approved disinfectants is continued and seemed to be a valuable instrument. In the German philosophy consumer should not be only dependent on the information of companies and industries.

To come back to scientific purpose, this study suggests that the norm methods to test ABHR efficacy must be improved for better standardization, but we don't agree with all priorities proposed by Kampf et al. to improve the validity of products and efficacy claims. We agree with the fulfilling of European pertinent norms and with the necessity to revise regularly the European norms to take into account the observed bias as for example the type of columns in the virucidal test. A better public control of norms and biocide authorizations is needed notably because of the increasing number of news ABHR products.

\section{Endnote}

${ }^{a}$ The Association for Applied Hygiene is an Association of different German Societies for Hygiene including the German Society for Hospital Hygiene.

\section{Acknowledgments}

Raphaelle Girard, Pierre Parneix, Raoul Baron, Olivia Keita Perse, Jean Christophe Lucet, Serge Aho, Béatrice Croze, Daniel Zaro-Goni who participated to the preparation of this editorial.

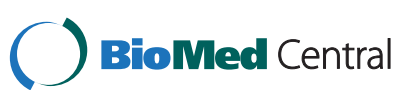

(c) 2014 Berthelot and Exner; licensee BioMed Central Ltd. This is an Open Access article distributed under the terms of the Creative Commons Attribution License (http://creativecommons.org/licenses/by/2.0), which permits unrestricted use, distribution, and reproduction in any medium, provided the original work is properly credited. The Creative Commons Public Domain Dedication waiver (http://creativecommons.org/publicdomain/zero/1.0/) applies to the data made available in this article, unless otherwise stated. 


\section{Author details}

${ }^{1}$ French Society for Hospital Hygiene (SF2H), Saint-Etienne, France. ${ }^{2}$ German Society of Hospital Hygiene and Chairman of the Disinfection, Committee of the German Association for Applied Hygiene, Bonn, Germany.

Received: 13 January 2014 Accepted: 6 April 2014

Published: 14 April 2014

\section{References}

1. Kampf G, Ostermeyer C, Werner HP, Suchomel M: Efficacy of hand rubs with a low alcohol concentration listed as effective by a national hospital hygiene society in Europe. Antimicrob Resist Infect Control 2013, 2(1):19.

2. Kramer A, Rudolph P, Kampf G, Pittet D: Limited efficacy of alcohol-based hand gels. Lancet 2002, 359:1489-1490.

3. Girard R, Aho LS, Goetz ML, Labadie JC, Lejeune B, Members of the working group on hand disinfection of the French Society for Hospital Hygiene: Alcohol-based hand gels and hand hygiene in hospitals. Lancet 2002, 360:1510-1511. author reply 1511 .

4. Girard R, Aho LS, Aupée M, Berthelot P, Dumartin C, Erb M, Goetz ML, Lashéras A, Zaro-Goni D: Alcohol-based rubs for hand antisepsis. Lancet Infect Dis 2008, 8:584-585.

5. Surveillance and prevention of healthcare-associated infections. September 2010. Higher Council for Public Health, Ministry of health and French Society for Hospital Hygiene: http://www.sf2h.net/SF2H_english/SF2H_surveillanceand-prevention-guidelines-2010.pdf

doi:10.1186/2047-2994-3-11

Cite this article as: Berthelot and Exner: Comparative evaluation of alcoholic handrub: science or marketing? Antimicrobial Resistance and Infection Control 2014 3:11.

\section{Submit your next manuscript to BioMed Central and take full advantage of:}

- Convenient online submission

- Thorough peer review

- No space constraints or color figure charges

- Immediate publication on acceptance

- Inclusion in PubMed, CAS, Scopus and Google Scholar

- Research which is freely available for redistribution 